\title{
NILAI-NILAI HUMANISME DALAM DIALOG ANTAR AGAMA PERSPEKTIF GUS DUR
}

\author{
Muhammad Aqil \\ muhammadaqi1312@gmail.com \\ Pascasarjana UIN Sunan Kalijaga Yogyakarta
}

DOI: $10.21580 /$ wa.v6i1.4915

\begin{abstract}
The figure of Gus Dur is a unique figure and his thoughts are typical. For most people, his thoughts are difficult to guess and difficult to digest by ordinary lay people, making him a controversial figure as well as being admired. Gus Dur as a teacher of the nation and an intellectual figure is a person who upholds the values of humanism. His struggle in upholding human rights made him highly respected by people from various backgrounds and different identity backgrounds. In particular his defense of the rights of oppressed minorities from both religion and ethnicity. Solving problems during conflicts by promoting dialogue that upholds human values makes Abdurrahman a reliable mediator. His thinking about humanism, is ideally implemented in interfaith dialogue, he offers a concept that is more focused on the human side, human rights themselves rather than dialogue that is theological in nature. , "Here a Humanist Is Buried". That is, he wants to be remembered as a humanitarian fighter. The title of a humanist figure seems more appropriate for him. Because Gus Dur's humanism really departed from the deepest values of Islam, which transcended ethnicity, territoriality, to the limit of statehood.
\end{abstract}

Keywords: Gus Dur, Humanism, Interfaith Dialogue

\begin{abstract}
Abstrak
Sosok Gus Dur merupakan sosok yang unik dan pemikirannya tergolong tipikal. Bagi kebanyakan orang, pemikiran beliau yang susah di tebak dan sulit dicerna oleh orang awam kebanyakan, menjadikannya sebagai sosok yang kontroversial sekaligus dikagumi. Gus Dur sebagai guru bangsa dan tokoh intelektual adalah sosok yang sangat menjunjung tinggi nilai-nilai humanisme. Perjuangannya dalam menegakkan hak asasi manusia menjadikannya sangat disegani oleh masyarakat dari berbagai kalangan dan latar belakang identitas
\end{abstract}


yang berbeda. Terkhusus pembelaannya terhadap hak-hak kelompok minoritas yang tertindas baik dari agama maupun etnis. Pemecahan masalah saat terjadi konflik dengan mengedepankan dialog yang lebih menjunjung nilai-nilai kemanusiaan menjadikan Gus Dur sebagai sosok mediator yang handal. Pemikirannya tentang humanism, sangat ideal diimplemantasikan dalam dialog antar agama, beliau menawarkan konsep yang lebih focus kepada sisi kemanusiaan, hak-hak manusia itu sendiri daripada dialog yang sifatnya teologis. Gus dur merupakan sosok yang sangat humanis beliau pernah berpesan agar di pusaranya dipahat sebuah tulisan, "Di Sini Dimakamkan seorang Humanis". Artinya, dia ingin dikenang sebagai pejuang kemanusiaan. Gelar tokoh humanis agaknya lebih tepat disematkan kepadanya. Sebab, humanisme Gus Dur benar-benar berangkat dari nilai-nilai Islam paling dalam, yang melampaui etnis, teritorial, hingga batas kenegaraan.

Kata kunci: Gus Dur, Humanisme, Dialog Antar Agama

\section{A. Pendahuluan}

Agama adalah sebuah keyakinan yang dimiliki oleh manusia, yang yakin berasal dari sang Pencipta dan segala aturan yang menyertainya. Agama merupakan seperangkat konsep, aturan hidup yang dilaksanakan oleh para pemeluknya. Berbicara tentang agama kecenderungan subjektivitas sulit dielakkan. Seorang pakar dan ahli Perbandingan Agama A. Mukti Ali mengatakan bahwa barangkali tak ada kata yang paling sulit diberi pengertian dan definisi selain dari kata 'agama' ${ }^{1}$.sehingga setiap kali membahas agama akan membawa emosional keagamaan ke dalam setiap kejiannya.

Keberagaman agama di dunia merupakan sebuah fakta tak terbantahkan atau lebih sering disebut dengan pluralitas agama. Pluralitas merupakan sebuah Sunnatullah. Hal ini haruslah disadari oleh setiap manusia, bahwa mustahil di era kondisi saat ini tidak bersinggungan atau berinteraksi dengan orang lain yang berbeda keyakinan atau agama. Sikap yang muncul sebagai upaya menjalankan ajaran agama di masing-masing penganut agama cenderung memunculkan sikap eksklusif, merasa paling benar dan paling hebat. Hal ini akan menimbulkan rasa ketidaksenangan dan kecaman dari penganut agama lain yang merasa disalahkan.

Sikap seperti ini dalam kondisi interaksi yang heterogen-pluralis tidak akan bisa diterima karena akan menimbulkan konflik antar penganut agama yang yakin bahwa agamanya adalah agama yang paling benar. Berbagai fakta sejarah menunjukkan bahwa agama menjadi motor penggerak kekerasan serta konflik yang berkepanjangan. ${ }^{2}$ Ini merupakan hasil dari interaksi yang eksklusif dalam sikap keberagamaan. Kekerasan atas

${ }^{1}$ A. Mukti Ali, Ilmu Perbandingan Agama di Indonesia (Yogyakarta: IAIN Sunan Kalijaga Press, 1988), hlm. 47.

${ }^{2}$ Dalam rentangan sejarah perang di dunia, setidaknya terekam ada jutaan manusia terbunuh dalam perang, khususnya perang yang bertalikelindanya agama atau keyakinan di dalamnya, untuk lebih lengkap lihat http://necrometrics.com/pre1700a.htm. 
nama agama adalah justifikasi teologis yang dibenarkan oleh sebagian penganut agama, sepertinya tidak ada jalan lain dalam meredam konflik yang terjadi antar umat beragama di dunia ini. Contoh kasus Poso di Indonesia, di Timur Tengah melibatkan umat Islam dan non Islam. Di India Hindu dengan Buddha, dan banyak lagi meskipun agama bukanlah satusatunya faktor konflik, tetapi agama sangat berperan di dalamnya. ${ }^{3}$

Diakui atau tidak, yang menjadi salah satu penyebab utama terjadinya konflik di masyarakat yang selama ini adalah adanya paradigma keberagamaan yang masih eksklusif . Eksklusifisme masyarakat tersebut tampak dalam pola pikir beragama yang relatif masih dispariasitas, dan masih terdapat sekat-sekat primordialisme. Oleh karena itu, dibutuhkan sebuah paradigma baru dalam mengatur hubungan tersebut. Muhammad Ali mengatakan, untuk mencegah agar pemahaman kemasyarakatan yang eksklusif ini tidak terus berkembang maka perlu diambil langkah preventif, yaitu membangun pemahaman kemasyarakatan yang lebih inklusiv dan humanis.

Dalam upaya memperkecil konflik antar umat beragama, berbagai pakar dan ahli perbandingan agama khususnya yang peduli terhadap kajian dan studi agama-agama berupaya mencari konsep yang mampu memberikan pemahaman baru akan arti pentingnya kebersamaan dan keharmonisan antar umat beragama. ${ }^{4}$

Berbicara tentang humanism dalam hal ini menurut hemat penulis pemikiran gus Dur merupakan salah satu pemikiran yang bisa digunakan dalam ranah dialog antar agama. pemikirannya yang bersifat humanis lebih mengedepankan nilai-nilai kemanusiaan dari pada nilai-nilai teologis dalam berdialog menjadikan gus dur dikenal sebagai bapak pluralisme di Indonesia. Konsep yang mengedepankan nilai-nilai kemanusiaan dalam dialog antar agama merupakan cara yang dapat menggerus sikap eklusif dari masing-masing pemeluk agama. gus dur dalam pemikirannya yang sangat menjunjung tinggi sisi kemanusiaan menawarkan nilai-nilai yang bisa diaplikasikan dalam ranah dialog antar agama. misalnya ketauhidan, kemanusiaan, keadilan, kesetaraan, pembebasan, kesederhanaan, persaudaraan, kesatriaan, dan kearifan.

Sehingga cara seperti ini setidaknya dapat menjadi sebuah ikhtiar agar konflik keagamaan di masa depan tidak akan terjadi lagi. Dialog yang sifatnya pada ranah doktrin atau dogma tidak akan mendapatkan titik temu sebab masing-masing agama mempunyai doktirn yang berbeda-beda yang tidak mungkin bisa disatukan. Namun, etika dan prilaku agama-agama memiliki banyak kesamaan seperti nilai-nilai kemanusiaan dan hak-hak dari manusia itu sendiri. Maka dalam hal ini dialog antar agama bukan hanya bertujuan untuk hidup bersama secara damai dengan cara membiarkan pemeluk agama lain 'ada' (koeksistensi), melainkan juga berpartisipasi secara aktif meng-'ada'-kan pemeluk agama lain tersebut (pro-eksistensi).

${ }^{3}$ Syahrin Harahap, "Prolog: Agama-Agama dan Masa Depan Bersama," dalam Arifinsyah, Dialog Global antar Agama Membangun Budaya Damai dalam Kemajemukan (Bandung: Citapustaka Media Perintis, 2009), hlm. 2.

${ }^{4}$ Surya Adi Sahfutra, Gagasan Pluralisme Agama Gus Dur untuk Kesetaraan dan Kerukunan, Religi, vol. 10, No. 1, Januari 2014, hlm. 90. 
Pandangan humanism Gus Dur berkaitan dengan masalah pluralisme dengan menekankan pandangan keterbukaan untuk menemukan kebenaran dimanapun juga. Humanisme yang ditekankan gus dur adalah bentuk Pluralisme dalam bertindak, sebab hal ini yang akan melahirkan bentuk toleransi.

Dialog yang mengedepankan nilai-nilai humanisme dapat menjadikan masingmasing pemeluk agama mempunyai satu tujuan yang sama yaitu kemanusiaan. Jika dialog sifatnya hanya berkutat pada ranah teologis, maka yang terjadi masing-masing pemeluk akan terikat pada tendensiusnya masing-masing yang berakibat pada sikap merasa paling benar sendiri serta lebih mengedepankan kepentingan pribadi ataupun kelompoknya.

Gus dur merupakan sosok yang sangat humanis beliau pernah berpesan agar di pusaranya dipahat sebuah tulisan, "Di Sini Dimakamkan seorang Humanis". Artinya, dia ingin dikenang sebagai pejuang kemanusiaan. Gelar tokoh humanis agaknya lebih tepat disematkan kepadanya. Sebab, humanisme Gus Dur benar-benar berangkat dari nilai-nilai Islam paling dalam, yang melampaui etnis, teritorial, hingga batas kenegaraan.

Berkaca pada pemikiran gus dur tentang humanisme di atas maka dalam tulisan ini akan dijelaskan bagaimana membangun nilai-nilai humanisme dalam dialog antaragama menurut pandangan gus dur.

\section{B. Biografi Singkat Gus Dur}

Abdurrahman wahid memiliki nama asli Abdurrahman al-dakhil yang berarti sang penakluk atau sang pendobrak. Nama tersebut merupakan pemberian sang ayah. Nama ini terinspirasi dari seorang khalifah Abdurrahman yang berhasil menaklukan Spanyol, dan mendirikan dinasti Islam disana. Namun setelah ayahnya meninggal, nama depan ayahnya diambil dan diletakkan diakhir namanya, jadilah nama Abdurrahman Wahid. ${ }^{5}$

Abdurrahman Wahid yang sering disebut dengan Gus Dur lahir pada tanggal 7 September 1940. Tetapi Gus Dur selalu merayakan hari ulang tahunnya pada 4 Agustus, tampaknya teman-teman dan keluarganya tak sadar bahwa hari lahir Gus Dur bukanlah tanggal itu. ${ }^{6}$ Ayah Gus Dur adalah Kiai Wahid Hasyim, putra Kiai Hasyim Asy'ari, dan ibunya Solichah, putra Kiai Bisri Syansuri. Sejak kecil Gus Dur dididik dan dibesarkan dalam keluarga pesantren dan di bawah naungan keluarga ulama. Sejak usia 5 tahun Gus Dur sudah lancar membaca, dan dalam pertumbuhannya dia adalah sebagai seorang pecandu bacaan. Gus Dur memulai pendidikan dasarnya di SD KRIS di Jakarta Pusat. Ia mengikuti pelajaran di kelas tiga dan kemudian di kelas empat. Akan tetapi dia kemudian pendah ke SD Matraman Pertiwi, yang terletak di dekat rumah keluarga yang baru di

${ }^{5}$ Muhtalim, Negara Islam Nir-Kekerasan Studi Pemikiran Gus Dur, (Yogyakarta: Karkasa, 2017), hlm. 63.

${ }^{6}$ Di beberapa buku banyak tertulis bahwa tanggal lahir Gus Dur adalah 4 Agustus 1940. akan tetapi menurut Greg Barton ketika wawancara dengan Gus Dur, sebenarnya Gus Dur memang dilahirkan pada hari ke empat, bulan ke delapan. Padahal tanggal itu adalah menurut kalender Islam, yakni bulan Sya'ban. Tetapi pejabat catatan sipil setempat mencatat tanggal 4 Agustus sebagai tanggal lahir Gus Dur. Lihat Greg Barton, Biografi Gus Dur The Authorized Biography of Abdurrahman Wahid, terj, Lie Hua, (Yogyakarta: Saufa bekerja sama dengan IRCiSoD dan LKiS, 2016), hlm. 25. 
Matraman, Jakarta Pusat. Jelas pada tahap ini, pendidikan Gus Dur sepenuhnya bersifat sekuler. Namun, tentu saja ia telah mempelajari Bahasa Arab ketika kecil dan mempunyai cukup pengetahuan untuk dapat membaca Al-Qur'an.

Setelah selesai SD ia melanjutkan belajar di empat pesantren yaitu pesantren Tegalrejo di Magelang dan pesantren krapyak di Yogyakarta. Di pesantren ini Gus Dur belajar bahasa Arab hukum-hukum Islam dan hadis. Tahun-tahun pertama di pesantren dijalani dengan kesederhanaan dan dijalaninya untuk menghafal dan mempelajari kitabkitab. ${ }^{8}$

Tahun 1963 Gus Dur menerima beasiswa dari kementrian agama RI untuk belajar di Universitas Al-Azhar Kairo Mesir pada Departemen of Higher Islamic and Arabic Studies. Namun di Mesir Gus dur rupanya lebih memilih sebagai penikmat hidup ketimbang sebagai pelajar yang serius. Hal ini terjadi sebab menurutnya, materi yang diberikan sudah banyak ia pelajari dan ia menolak metode belajar yang digunakan universitas. Ketidaksetujuannya terhadap metode pendidikan di Universitas Al-Azhar rupanya sangat membuat Gus Dur tidak nyaman. Studinya di Al-Azhar gagal dan pada tahun 1966 ia diberitahu pihak universitas untuk mengulang pelajaran. Pada saat bersamaan, ia menerima beasiswa dari Universitas Baghdad. Universitas inilah yang menyelamatkan pendidikan prasarjana Gus dur. ${ }^{9}$ Berbeda dengan pendidikan Al-Azhar di Mesir pendidikan yang dipelajari di Universitas Baghdad lebih bercorak sekuler dan bergaya barat. ${ }^{10}$

Tahun 1970, Gus dur menyelesaikan pendidikannya di Universitas Baghdad. Ia kemudian pergi ke Belanda untuk meneruskan pendidikannya di Universitas Leiden. Tetapi ia harus menelan kekecewaan karena pendidikannya di Universitas Baghdad rupanya kurang diakui oleh Universitas Leiden. Dari Belanda, Gus Dur kemudian pergi ke Jerman dan Prancis sebelum akhirnya kembali ke Indonesia pada tahun $1971 .{ }^{11}$

Latar belakang pendidikan dan pengalaman Gus Dur dengan wacana-wacana kritis telah membuat dirinya siap berhadapan dengan dinamika sosial, politik, serta dan wacana ke Islaman kontemporer. ia juga menggeluti kegiatan politik yang diawali dengan keterlibatannya dalam dunia lembaga swadaya masyarakat. Pemikiran Gus Dur lahir ditengah era developmentalisme dalam kekuasaan Orde Baru yang bercorak kompromistik antara varian ekonomi dan politik yang menyatu dalam agenda besar modernisasi. ${ }^{12}$

Gus Dur banyak meninggalkan karya intelektual sebagai respon atas situasi yang ada pada waktu itu. Selain dalam bentuk buku, karya lain yang paling banyak ditinggalkan adalah dalam bentuk artikel, opini, atau esai. Pemikirannya tentang tentang persoalan-

\footnotetext{
${ }^{7}$ Greg Barton, Biografi Gus Dur The Authorized Biography of Abdurrahman Wahid, terj. Lie Hua, (Yogyakarta: Saufa bekerja sama dengan IRCiSoD dan LKiS, 2016), hlm. 26-47.

8 Muhtalim, Negara Islam..., hlm. 65

${ }^{9}$ Ali Maykur Musa, Pemikiran dan Sikap Politik Gus Dur, (Jakarta: Erlangga, 2010), hlm. 7.

${ }^{10}$ Muhtalim, Negara Islam..., hlm. 69.

11 Ali Maykur Musa, Pemikiran dan Sikap..., hlm. 8.

${ }^{12}$ Suwardiyamsyah, Pemikiran Abdurrahman Wahid tentang Toleransi Beragama, AL-IRSYAD, Vol. 8, No. 1, Januari - Juni 2017, hlm. 117.
} 
persoalan sosial dan gerakan sosial di luar pesantren baru dimunculkannya setelah berjumpa dengan intelektual lain dan aktivis sosial pada era tahun 1980-an. Dalam buku Muslim di Tengah Pergumulan, karya Gus Dur ini mulai merambah pada modernisasi, HAM (Hak Asasi Manusia), demokrasi, dan reinterpretasi ajaran Islam. Sedangkan era 1990-an, pemikiran Gus Dur secara umum bersentuhan dengan persoalan humanisme, kepartaian, dan demokrasi. ${ }^{13}$

\section{Pengertian Humanisme}

Humanisme juga berasal dari kata humanitas yang kemudian diberi akhiran isme menjadi humanisme yang menunjukkan istilah aliran atau paham. ${ }^{14}$ Dalam bahasa Indonesia kontemporer humanism adalah pahama yang mempunyai tujuan menumbuhkan rasa perikemanusiaan dan bercita-cita untuk menciptakan pergaulan hidup manusia yang lebih baik. ${ }^{15}$ Humanisme bisa diartikan sebagai paham di dalam aliran-aliran filsafat yang hendak menjunjung tinggi nilai dan martabat manusia, serta menjadikan manusia sebagai ukuran dari segenap penilaian, kejadian, dan gejala di atas muka bumi ini. Istilah humanisme memiliki keterkaitan dengan istilah yang berakar dari kata yang sama, yakni humaniora, humanities, (latin: humanior), yaitu ilmu-ilmu pengetahuan yang bertujuan membuat manusia lebih manusiawi, dalam artian membuat manusia lebih berbudaya. Humanisme juga berasal dari studi humanitatis yang mengandung arti kesenian liberal atau studi kemanusiaan dari Cicero.

Inti kesenian liberal adalah membebaskan peserta didik dari kebodohan dan kepicikan melalui pengembangan intelektual yang meliputi tata bahasa, retorika (berbicara), syair, sejarah, dan filsafat moral. Dalam studia humanitatis, ilmu-ilmu ini dianggap paling mampu mengembangkan potensi manusia untuk berfikir dan bertindak secara bebas dan mandiri. ${ }^{16}$ Kesenian liberal bukan berarti kesenian yang tidak mengenal etika, pemberian nama liberal karena pembelajaran ini bebas untuk semua golongan, tidak mengenal kasta.

Senada dengan Siswanto Masruri, Zainal Abidin juga memaknai humanisme dengan arti yang lebih dekat dengan seni liberal yang mendorong kebebasan berekspresi yang akan menjadikan manusia bias sederajat antara satu dengan lainnya, ia mengatakan:

"Istilah "humanisme" ini berasal dari kata "humanitas" yaitu pendidikan menusia dan dalam bahasa Yunani disebut Paideia: pendidikan yang didukung oleh manusia-manusia yang hendak menempatkan seni liberal sebagai materi dan sarana utamanya. Mereka yakin dengan seni liberal, manusia akan tergugah untuk menjadi manusia, menjadi manusia bebas

13 Suwardiyamsyah, Pemikiran Abdurrahman..., hlm. 117.

${ }_{14}$ Zainal Abidin, Filsafat Manusia, Memahami Manusia Melalui Filsafat, (Bandung: Rosda Karya, 2000), hlm. 41.

${ }^{15}$ Peter Salim dan Yenny Salim, Kamus Besar Bahasa Indonesia Kontemporer, (Jakarta: Modern English Press, 1991), hlm. 541.

16 Siswanto Masruri, Humanitarianisme Soedjatmoko: Visi Kemanusiaan (Yogyakarta: Pilar Media, 2005), hlm. 98. 
yang tidak terkungkung oleh kekuatan-kekuatan dari luar dirinya. Humanisme pada waktu itu dengan tema pokoknya kebebasan menentang dogma gereja, namun kebebasan yang diperjuangkan bukanlah kebebasan absolut atau sebagai anti tesis dari determinatisme abad pertengahan. Sebab kebebasan yang mereka perjuangkan adalah kebebasan berkarakter manusiawi dan mereka juga tidak mengkhayal adanya kekuatan-kekuatan metafisik atau ilahiyah. Pada pokoknya, menurut mereka kebabasan itu ada, dan perlu dipertahankan dan diekspresikan". ${ }^{17}$

Sedangkan Chabib Toha mengartikan humanisme adalah nilai-nilai obyektif yang dibatasi oleh kultur tertentu, nilai kebebasan, kemerdekaan, kebahagiaan. Persamaan hak adalah nilai-nilai kemanusiaan yang dibangun di atas fondasai individualisme dan demokrasi. ${ }^{18}$ Maka ketika pemahaman tentang humanisme ini telah melekat pada diri individu, realisasi dari pemahamannya tersebut adalah bersikap humanis.

Bersikap humanis berarti memberikan penghormatan dan penghargaan kepada orang lain, tidak tergantung dari ciri-ciri atau kemampuan-kemampuannya, melainkan semata-mata dari kenyataan bahwa dia adalah seorang manusia. Bersikap humanis juga diartikan sebagai solidaritas berprinsip dengan orang lain apapun kondisi orang tersebut, dan bahwa orang lain mudah terluka. Suatu kemampuan untuk melihat dan merasakan kondisi orang lain tanpa memandang sekat-sekat primordial dan sosialnya. Penolakan terhadap ketidakadilan, fairness dan cinta keadilan adalah sikap berprinsip yang mewarnai seseorang dalam seluruh dimensi hidupnya. Ini berarti, humanisme tidak terikat pada batas-batas ideologi, agama atau legitimasi-legitimasi teoritis lain. ${ }^{19}$

Lebih lanjut menurut Magnis Suseno pribadi yang humanis adalah pribadi yang memiliki sikap-sikap tahu diri, bijaksana, bertolak dari keterbatasannya maka mengambil sikap yang wajar, terbuka, dan melihat berbagai kemungkinan. Bersikap positif terhadap sesama, tidak terhalang oleh kepicikan primordialisme, suku, bangsa, agama, etnik, warna kulit, dan lain-lain. Ia anti kepicikan, fanatisme, kekerasan, penilaian-penilaian mutlak, tidak mudah mengutuk pandangan orang lain. Sebaliknya, ia bersikap terbuka, toleran, mampu menghormati keyakinan orang lain termasuk jika ia tidak menyetujuinya, dan mampu melihat yang positif di balik perbedaan. Oleh karena itu, sikap humanis adalah sikap menghargai hak-hak sesama manusia. Sebuah sikap yang menghargai fitrah kebebasan yang menjadi inti dari naluri kemanusiaan (al hurriyah). Didalamnya terdapat hak untuk hidup, berfikir, dan hak-hak lain, sehingga orang yang bersifat Humanis tidak lagi memayoritas-kan diri serta menghargai keberagaman. ${ }^{20}$

17 Zainal Abidin, Filsafat Manusia,..,hlm. 41.

18 Zulkifli Nelson dan Dardiri, Inklusivisme dan Humanisme Pesantren, TOLERANSI: Media Komunikasi umat Beragama Vol. 8, No. 2, Juli-Desember 2016, hlm. 139.

${ }^{19}$ Zulkifli Nelson dan Dardiri, Inklusivisme..., hlm. 140.

${ }^{20}$ Zulkifli Nelson dan Dardiri, Inklusivisme..., hlm. 140. 


\section{Humanisme Gus Dur}

Abdurrahman Wahid adalah seorang tokoh di antara sekian banyak tokoh Islam yang konsisten mengusung gagasan tentang humanisme. ${ }^{21}$ Humanisme Gus Dur ini adalah humanism Islam yang berkaitan dengan berbagai ajaran Islam tentang toleransi dan keharmonisan social yang menyangkut budaya muslim yang mendorong umat Islam tidak seharusnya takut terhadap suasana plural yang ada di tengah masyarakat modern, sebaliknya harus merespon dengan positif. ${ }^{22}$ Humanisme yang ditekankan Gus Dur adalah bentuk pluralism dalam bertindak dan berpikir, sebab hal ini yang akan melahirkan bentuk toleransi. Sikap toleran yang tidak bergantung pada apapun, tetapi pengakuan atas pluralitas merupakan persoalan hati, persoalan perilaku. ${ }^{23}$ Gus Dur mengembangkan pandangan anti eklusivisme agama. hal ini berdasarkan fenomena berbagai peristiwa kerusuhan, kekerasan dan radikalisasi yang berkedok agama di beberapa tempat adalah akibat adanya ekslusivisme agama. ${ }^{24}$ pada berbagai kasus kekerasan ini agama, agama telah menjadi sumber ketidakadilan dan ketidakharmonisan antar sesama umat manusia. Agama menjadi pemisah antara manusia dengan label demi agama. pada kondisi yang seperti ini agama telah manjadi institusi yang bersikap ekslusif, hanya berkutat pada hal yang bersifat retorik, ideologis, dan tidak mampu berbuat banyak pada kehidupan yang sesungguhnya. Agama telah kehilangan fungsi sosialnya sebagai penegak kesejahteraan, keharmonisan kehidupan, keadilan, dan kesetaraan.

Lebih lanjut Gus Dur menunjukan ketidaksepahamannya terhadap berbagai gerakan fundamentalis yang cenderung menggunakan kekerasan. Menurutnya, semua tindakan yang menggunakan kekerasan dengan label agama adalah bentuk dari pengingkaran dan pendangkalan terhadap agama itu sendiri sebagai jalan keselamantan serta akan mereduksi nilai-nilai humanism universal yang dikandung dalam agama tersebut. Karena itu, tidak ada alasan saat ini untuk mengembangkan sikap permusuahan kepada kelompok agama lain selama itu masih memungkinkan untuk berdialog. ${ }^{25}$

${ }^{21}$ Abdurrahman Wahid menggunakan istillah humanitarianisme, yang dimaksudkan di sini untuk membicarakan dan apresiasi yang luas terhadap segala hal yang baik dalam manusia ditambah dengan perhatian dan kesejahteraan setiap individu. Karena itu istillah humanitarinasme tersebut hampir sama dengan pengertian umum humanisme sekuler. Tetapi berbeda dengan humanisme sekuler, humanitarianisme juga dipakai dalam seruan ketertundukan kepada Tuhan. Maka begitu penting, dan merupakan pikiran pokok Abdurrahman Wahid bahwa ketertundukan dan takhzim kepada Tuhan merupakan asas paling tinggi dalam ideology humanitarianisme. Greg Barton, gagasan Islam Liberal di Indonesia: pemikiran NeoModernisme Nurcholish Madjid, Djohan Effendi,Ahmad Wahid dan Abdurrahman Wahid (Jakarta:ParamadinaPustaka Antara, 1999), hlm. 407.

${ }^{22}$ Greg Barton, Gagasan Islam Liberal di Indonesia, hlm. 334.

${ }^{23}$ Greg Barton, Gagasan Islam Liberal di Indonesia, hlm. 419.

${ }^{24}$ Lihat Abdurrahman Wahid, "Dialog agama dan masalah pendangkalan agama”, dalam Komarudin Hidayat dan Ahmad Gaus, Passing Over: Melintasi Batas Agama (Jakarta: Gramedia Pustaka Utama, 1998), hlm. 52 .

25 Abdurrahman Wahid, Dialog agama dan masalah pendangkalan agama..., hlm. 53. 
Berbagai fakta kemanusiaan tersebut yang merupakan titik berangkat yang jelas bagi pluralism, yang berarti juga dialog antar agama. ketika mengabaikan nilai humanisme maka sebenarnya dialog telah gagal sebelum dimulai. Dalam pandangan Gus Dur aspek humanism ini juga harus diturunkan dalam berbagai term penting, antara lain: jaminan kebebasan dalam beragama, jaminan adanya perlindungan akan hak-hak dasar kemanusiaan, budaya yang demokratis, dan perlindungan terhadap kalangan minoritas. Humanism Gus Dur ini menjadi wacana yang sangat penting, karena itu sikap anti kekerasan merupakan nilai dasar yang harus dikembangkan sebagai ujung tombak dalam menjalani kehidupan beragama, berbangsa dan bernegara. ${ }^{26}$

\section{E. Humanisme 9 Nilai Gus Dur dan Implementasinya dalam Dialog Antar agama}

Dalam humanism Gus Dur yang menjadi pokok pembahasan adalah sembilan nilai Gus Dur yang dirumuskan oleh Gusdurian. Sebuah komunitas pecinta Gus Dur yang senantiasa merawat dan melestarikan pemikiran-pemikiran Gus Dur tentang keagamaan dan ke Indonesiaan. Sembilan nilai Gus Dur tersebut adalah; Ketauhidan, Kemanusiaan, Keadilan, Kesetaraan, Pembebasan, Kesederhanaan, Persaudaraan, Keksatriaan, Kearifan Lokal. Dari sembilan nilai Gus Dur tersebut akan dijelaskan pokok-pokok humanis Gus Dur melalui pendekatan dalam aspek beragama, bermasyarakat dan bernegara. ${ }^{27}$

Ke 9 nilai ini jika diimplementasikan ke dalam dialog antar agama dapat menjadikan dialog antar agama sifatnya semakin inklusif. Dalam dialog masing-masing kelompok tidak lagi bersikap ekslusif disebabkan karena adanya perbedaan doktrin dan dogma dari masing-masing agama. Perbedaan teologis yang sebelumnya menjadi penyebab adanya sekat dari masing-masing kelompok beragama bisa disatukan atas dasar kemanusiaan. Dan 9 nilai Gus Dur bisa menjadi sebuah gagasan yang dapat diterapkan dalam berdialog antar umat beragama.

Gagasan Gusdur mengenai toleransi dan dialog antar agama atau antar iman tersingkronisasi dalam pemikirannya mengenai pluralisme. Apabila seseorang berpikir positif tentang pluralisme, maka otomatis di dalamnya sudah ada unsur-unsur yang menunjukkan sikap toleran dalam keberbedaan. Th. Sumartana, seorang penganut Katolik menilai bahwa Gusdur melihat perbedaan agama-agama cenderung merupakan perbedaan

${ }^{26}$ Kekerasan dan tindakan intoleran lainnya yang ada di Indonesia merupakan gejala kultural bagi masyarakat yang berada di tengah transformasi dari masyarakat tradisional kepada masyarakat postkolonialisme. Beberapa hal yang mendorong adanya budaya kekerasan yang ada di Indonesia empat factor utama, yaitu: pertama, factor kegagapan budaya, kedua, akumulasi kebencian dalam masyarakat yang diawali dari prejudice (anggapan) yang salah terhadap pemeluk agama lain, ketiga, masyarakat Indonesia telah terjebak dalam budaya intoleran, tidak menerima pluralitas tradisi, cara berkomunikasi, cara pandang kehidupan dan tekanan terhadap tradisi, keemoat, politik yang tidak berpihak kepada keadilan yang dijalankan oleh orde baru, karena politik yang dijalankan adalah bentuk pelestarian budaya kekerasan yang dilembagakan. Lebih lanjut baca, Franz Magnis Suseno,"factor-factor yang mendasari terjadinya konflik Antar Etnis dan agama di Indonesia: pencegahan dan pemecahan", dalam konflik komunal di Indonesia saat ini (Jakarta:INIS, 2003), hlm. 120-123.

${ }^{27}$ Gusdurian.net, " 9 Nilai Pemikiran Gus Dur", http://www.gusdurfiles.com Sembilan nilai utama Gus Dur 
yang berada dalam tataran kemanusiaan dan tetap yakin bahwa sesungguhnya yang menjadi hakim untuk mengatakan seorang masuk syurga atau neraka adalah Tuhan. Bahkan ia mengatakan informasi dan ekspresi diri yang dianggap merugikan Islam sebenarnya tidak perlu dilayani. Cukup di imbangi dengan informasi dan ekspresi diri yang positif konstruktif. $^{28}$

\section{Ketauhidan}

Ketauhidan bersumber dari keimanan kepada Allah sebagai yang Maha Ada, satusatunya Dzat Hakiki yang Maha Cinta Kasih, yang disebut dengan berbagai nama. Ketauhidan didapatkan lebih dari sekedar diucapkan dan dihafalkan. Tetapi juga disaksikan dan disingkapkan. Ketauhidan menghujamkan kesadaran terdalam bahwa Dia adalah sumber dari segala sumber dan rahmat kehidupan di jagad raya. Pandangan ketauhidan menjadi poros nilai-nilai ideal yang diperjuangkan Gus Dur melampaui kelembagaan dan birokrasi agama. ketauhidan yang bersifat ilahi itu diwujudkan dalam perilaku dan perjuangan sosial, politik, ekonomi, dan kebudayaan dalam menegakkan nilai-nilai kemanusiaan. $^{29}$

Atas landasan ketauhidan itulah pemikiran Gur Dur dalam soal sosial, politik, ekonomi, dan kebudayaan dibangun, serta kesemuanya aspek tersebut diisi dengan nilainilai kemanusiaan. Lebih jauh lagi, pada nilai kedua dari sembilan nilai pemikiran Gus Dur tersebut, secara jelas dirumuskan bahwa kemanusiaan itu bersumber pada ketauhidan.

\section{Kemanusiaan}

Kemanusiaan bersumber dari pandangan ketauhidan bahwa manusia adalah makhluk Tuhan paling mulia yang dipercaya untuk mengelola dan memakmurkan bumi. Kemanusiaan merupakan cerminan sifat-sifat keTuhanan. Kemuliaan yang ada dalam diri manusia mengharuskan sikap untuk saling menghargai dan menghormati. Memuliakan manusia berarti memuliakan penciptanya, demikian juga merendahkan dan menistakan Tuhan Sang Pencipta. Dengan pandangan inilah, Gus Dur membela kemanusiaan tanpa syarat. ${ }^{30}$

Dalam menyelesaikan konflik suku dan agama yang terjadi di Aceh, Sampit, Situbondo, Maluku dan lain-lain, Gus Dur mengedepankan jalan musyawarah dan dialog. Karena Gus Dur sangat memahami bahwa pelaku dan korban adalah sama-sama korban masa lalu. Yang mana mereka belum biasa menerima kematian sanak saudaranya. Rekonsiliasi dan saling memahami antar satu sama lain serta sikap menahan diri adalah solusi yang tepat dalam menyelesaikan konflik tersebut. Pemikiran ini lantas beliau sebar dalam forum kemanusiaan tingkat internasional. Sebagaimana respon beliau terhadap kekerasan dan konflik yang terjadi di negara lain, seperti Filipina, Pakistan, Afganistan dan lain-lain.

${ }^{28}$ Indo Santalia, K.H. Abdurrahman Wahid, Agama dan Negara, Pluralisme, Demokratisasi, dan Pribumisasi, Al-Adyan, Vol. 1, No. 2, Desember 2015.

${ }^{29}$ Gusdurian.net, " 9 Nilai Pemikiran Gus Dur", http://www.gusdurfiles.com Sembilan nilai utama Gus Dur.

${ }^{30}$ Gusdurian.net, " 9 Nilai Pemikiran Gus Dur", http://www.gusdurfiles.com Sembilan nilai utama Gus Dur. 


\section{Keadilan}

Keadilan bersumber dari pandangan bahwa martabat kemanusiaan hanya bisa dipenuhi dengan adanya keseimbangan, kelayakan, dan kepantasan dalam kehidupan masyarakat. Keadilan tidak sendirinya hadir di dalam realita kemanusiaan dan karenanya harus diperjuangkan. Perlindungan dan pembelaan pada kelompok masyarakat yang diperlakukan tidak adil merupakan tanggung jawab moral kemanusiaan. Sepanjang hidupnya, Gus Dur rela dan mengambil tanggung jawab itu, ia berpikir dan berjuang untuk menciptakan keadilan di tengah-tengah masyarakat. ${ }^{31}$

Keadilan adalah nilai dasar dalam membangun masyarakat, yaitu keadilan, persamaan dan demokrasi. Ketika ketidakadilan yang dialami oleh penganut Ahmadiyah, Gus Dur melindungi Ahmadiyah, yang merasa kehilangan karena pekerjaan dan status social. Gus Dur secara konsisten membela hak mereka yang hilang karena keyakinan pada ajaran Ahmadiyah. Gus Dur juga tampil melindungi HAM dan penegak keadilan, sebagaimana disampaikan oleh Taufik Kiemas ${ }^{32}$ :

Gus Dur juga mengusulkan pencabutan Tap MPRS No. XXV/1966 soal pembubaran Partai Komunitas Indonesia (PKI) dan pelanggaran penyebaran ajaran Marxisme. Komunisme dan Leninisme. Begitu juga, Gus Dur mengakhiri perlakuan diskrimainasi terhadap etnis Tionghoa, melaluin Inpres No. 6/2000 dan mencabut Inpres 14/1967 tentang Agama, Kepercayaan dan Adat istiadat Cina. Intinya, Gus Dur membuka paradigma baru agar setiap orang mendapatkan perlakuan setara dalam hukum, tanpa membeda-bedakan warna kulit, etnis, agama, ataupun ideologinya. Ini bagian dari cita-cita Gus Dur yang ingin membangun Indonesia yang damai tanpa prasangka dan bebas dari segala kebencian." ${ }^{3}$

\section{Kesetaraan}

Kesetaraan bersumber dari pandangan bahwa setiap manusia memiliki martabat yang sama di hadapan tuhan. Kesetaraan meniscayakan adanya perlakuan yang adil, hubungan yang sederajat, ketiadaan diskriminasi dan subordinasi, serta marjinalisasi dalam masyarakat. Nilai kesetaraan ini, sepanjang kehidupan Gus Dur tampak jelas ketika melakukan pembelaan dan pemihakan terhadap kaum tertindas dan dilemahkan. Termasuk di dalamnya adalah kolompok minoritas dan kaum marjinal. ${ }^{34}$

Gus Dur melihat fakta keberagaman warga Indonesia haruslah tidak didominasi oleh golongan tertentu, atau agama tertentu. Keadilan, baginya, adalah milik semua agama, dan harus ditegakkan oleh umat beragama.

${ }^{31}$ Gusdurian.net, " 9 Nilai Pemikiran Gus Dur", http://www.gusdurfiles.com Sembilan nilai utama Gus Dur.

32 Mantan Ketua MPR RI/ Dewan Pembina DPP PDI-P

33 Aryanto Nugroho. Jejak Langkah Guru Bangsa Footprints Of The Guru, Keep Gus Dur's Spirit. (Semarang: EIN INSTITUTE. 2010), hlm. 23.

${ }^{34}$ Gusdurian.net, " 9 Nilai Pemikiran Gus Dur", http://www.gusdurfiles.com Sembilan nilai utama Gus Dur. 


\section{Pembebasan}

Pembebasan bersumber dari pandangan bahwa setiap manusia memiliki tanggung jawab untuk menegakkan kesetaraan dan keadilan untuk melepaskan diri dari berbagai bentuk belenggu. Semangat pembebasan hanya dimiliki oleh jiwa yang merdeka, bebas dari rasa takut, dan otentik. Dengan niai pembebasan ini, Gus Dur selalu mendorong dan memfasilitasi tumbuhnya jiwa-jiwa merdeka yang mampu membebaskan dirinya dan manusia lain. ${ }^{35}$

Dalam hal ini setiap kelompok beragama maka bebas untuk melaksanakan peribadatan atau ritual kepercayaan mereka masing-masing. Setiap umat beragama bebas mendapatkan hak-hak nya sebagai warga Negara. Seperti hak pendidikan, hak politik, hak kesehatan. Jika hal semacam ini diterapkan dalam dialog maka tidak ada lagi yang akan dideskriditkan. Sebab semua kelomopok mempunyai hak yang sama di mata hokum, karena yang menjadi tolak ukur dalam kebebasan bukan siapa yang mayoritas tapi dari sisi kemanusiaan.

\section{Kesederhanaan}

Kesederhanaan bersumber dari jalan pikiran subtansial, sikap dan perilaku hidup yang wajar dan patut. Kesederhanaan menjadi konsep kehidupan yang dihayati dan dilakoni sehingga menjadi jati diri. Kesederhanaan menjadi budaya perlawanan atas sikap berlebihan, materialistis, dan koruptif. Kesederhanaan Gus Dur dalam segala aspek kehidupannya menjadi pembelajaran dan keteladanan, materialistis, dan koruptif. Kesederhanaan Gus Dur dalam segala aspek kehidupannya menjadi pembelajaran dan keteladanan.

Kesederhanaan Gus Dur tampak ketika sebelum, ketika dan setelah menjadi presiden. Dari gaya berpakaian, meskipun Gus Dur cucu kiai besar dan keilmuan keagamaannya tidak diragukan, Gus Dur lebih nyaman berpakaian batik dan tidak memakai surban. Kepada kiai sepuh dan para habaib, Gus Dur lebih ta'dhim dan merendah diri. Misalnya kepada KH. Sonhaji Kebumen, KH. Abdullah Salam Pati, KH. Hamim Jazuli, Syaikh Yasin Al-Fadani, dan lain-lain. Gus Dur lebih memposisikan dirinya sebagai santri. ${ }^{36}$

\section{Persaudaraan}

Persaudaraan bersumber dari prinsip-prinsip penghargaan atas kemanusiaan, keadilan, kesetaraan, dan semangat menggerakkan kebaikan. Persaudaraan menjadi dasar untuk memajukan peradaban. Sepanjang hidupnya Gus Dur memberi teladan dan menekankan pentingnya menjunjung tingggi persaudaraan dan masyarakat, bahkan terhadap yang berbeda keyakinan dan pemikiran. Gus Dur tidak hanya bergaul dengan kaum sarungan saja, akan tetapi tokoh agama bukan Islam juga sangat akrab dengan Gus Dur.

${ }^{35}$ Gusdurian.net, " 9 Nilai Pemikiran Gus Dur”, http://www.gusdurfiles.com Sembilan nilai utama Gus Dur.

${ }^{36}$ Gusdurian.net, " 9 Nilai Pemikiran Gus Dur", http://www.gusdurfiles.com Sembilan nilai utama Gus Dur. 
Franz Magnis Suseno SJ. Mengakui peran Gus Dur dalam “mempersaudarakan” kelompok-kelompok yang terkotak-kotak oleh suku, ras, daerah, dan agama. Ia menjelaskan: Sesudah 40 tahun pemerintahan dari atas dan lebih dari 30 tahun penindasan, bangsa mengalami keretakan. Kemampuan untuk menghayati solitaritas tidak hanya dengan kelompok sempit: kelompok suku, kelompok antar agama, kelompok daerah, semakin menyusut. Primordialisme dan komunalisme katerikatan emosional eksklusif pada komunitasnya sendiri mengancam keutuhan bangsa. Gus Dur dan Mbak Megawati merupakan solidarity makers yang ideal. Kalau ada yang dapat mempersatukan, maka merekalah. ${ }^{37}$

Semangat persaudaraan inilah yang menjamin keutuhan NKRI. Maka semangat Bhineka Tunggal Ika yang dalam istilah populer Gus Dur disebut "pluralisme” mulai ditanamkan Gus Dur. Gus Dur juga berusaha untuk menghilangkan sekat-sekat antar umat beragama. Tak jarang Gus Dur berkomentar bahwa semua agama adalah sama. Hal ini haruslah dipahami bahwa yang dimaksud Gus Dur dalam kalimat itu adalah semua agama sama dalam mengajarkan kebaikan. Oleh karena itu, tidak ada alasan untuk saling bermusuhan karena agama yang berbeda.

\section{Kesatriaan}

Keksatriaan bersumber dari keberanian untuk memperjuangkan dan menegakkan nilai-nilai yang diyakini dalam mencapai keutuhan tujuan yang di ingin diraih. Proses perjuangan dilakukan dengan mencerminkan integritas pribadi, penuh rasa tanggung jawab atas proses yang harus dijalani dan konsekuensi yang dihadapi, komitmen yang tinggi serta istiqomah. Keksatriaan yang dimiliki Gus Dur mengedepankan kesabaran dan keikhlasan dalam menjalani proses, seberat apapun, serta dalam menyikapi hasil yang dicapainya. ${ }^{38}$

Ketika menjabat sebagai presiden, Gus Dur sering kali membuat kebijakan yang tidak menguntungkan posisinya. Gus Dur hanya melaksanakan apa yang ia yakini benar untuk kemaslahatan bangsa. Meski hal itu membuatnya berada dalam masalah. Seperti dijelaskan oleh Taufiq Kiemas "Gus Dur pun konsisten, ketika menjabat sebagai presiden, tanpa banyak berhitung untung rugi, ia mengoperasionalkan gagasan demokrasi dan pluralismenya. Kong $\mathrm{Hu}$ Chu diakui sebagai agama, komunitas Tionghoa mendapat pengakuan dan kebebasan mengekpresikan budayanya. Kelompok minoritas seperti memperoleh jaminan kebebasan.

\section{Kearifan lokal}

Kearifan Lokal bersumber dari nilai-nilai sosial budaya yang berpijak pada tradisi dan terbaik kehidupan masyarakat setempat. Kearifan Lokal Indonesia di antaranya berwujud dasar negara Pancasila, konstitusi UUD 1945, prinsip Bhineka Tunggal Ika, dan seluruh tata nilai kebudayaan Nusantara yang beradab. Gus Dur menggerakkan kearifan lokal dan

${ }^{37}$ Ahmad Suaedy dan Ulil Abshar Abdalla, Gila Gus Dur: Wacana Pembaca Abdurrahman Wahid (Yogyakarta: PT LkiS Printing Cemerlang, 2010), hlm. 17-18.

${ }^{38}$ Gusdurian.net, " 9 Nilai Pemikiran Gus Dur", http://www.gusdurfiles.com Sembilan nilai utama Gus Dur. 
menjadikannya sebagai sumber gagasan dan pijakan sosial-budaya-politik alam membumikan keadilan, kesetaraan, dan kemanusiaan, tanpa kehilangan sikap terbuka dan progresif terhadap perkembangan peradaban. ${ }^{39}$

Dikebanyakan kesempatan, Gus Dur seringkali terlihat mengenakan baju batik dan peci rotannya yang khas. Gus Dur lah yang mempopulerkan peci rotan Gorontalo. Sebagaimana obituari yang disampaikan Hakim Setyohadi49, pengawal pribadi Gus Dur: "Kemudian kulturalnya, beliau sangat menghargai budaya dan tidak membeda-bedakan asal usul ras, golongan, agama dan sebagainya. Beliau sangat erat dengan segala ragam budaya di Indonesia.

\section{F. Kesimpulan}

Bagi kebanyakan rakyat Indonesia Gus Dur adalah humanis yang ingin menegakkan demokrasi dan hak asasi manusia dalam arti yang sebenar-benarnya. Apa yang diperjungkannya adalah nilai-nilai kemanusiaan yang tidak lagi memandang unsur-unsur primordial. Gus Dur teramat sadar bahwa humanism yang masih dibatasi oleh sekat-sekat primordialisme hanya akan menjadi ancaman bagi obyektifitas perjuangan atas nilai-nilai kemanusiaan itu sendiri.

Dalam berpikir dan bahkan bertindak, Gus Dur bahkan melampaui batas-batas tafsir agama yang sempit, Islam bagi Gus Dur, sebagaimana halnya agama lain, adalah doktrin yang menjangkau nilai-nilai kemanusiaan secara universal dan menyeluruh. Bagi Gus Dur penghayatan terhadap nilai-nilai kemanusiaan adalah inti dari ajaran agama. Tanpa nilainilai tersebut dunia akan dipengaruhi oleh berbagai bentuk kekerasan dan konflik social. Penekanan pada pemahaman seperti ini semakin mengokohkan sikap humanism yang hendak dibangunnya.

\section{Daftar Pustaka}

Ali, Mukti, Ilmu Perbandingan Agama di Indonesia, Yogyakarta: IAIN Sunan Kalijaga Press, 1988.

Arifinsyah, Dialog Global antar Agama Membangun Budaya Damai dalam Kemajemukan, Bandung: Citapustaka Media Perintis, 2009.

Adi Sahfutra, Surya, Gagasan Pluralisme Agama Gus Dur untuk Kesetaraan dan Kerukunan, Religi, vol. 10, No. 1, Januari 2014.

Muhtalim, Negara Islam Nir-Kekerasan Studi Pemikiran Gus Dur, Yogyakarta: Karkasa, 2017.

Barton, Greg, Biografi Gus Dur The Authorized Biography of Abdurrahman Wahid, terj. Lie Hua, Yogyakarta: Saufa bekerja sama dengan IRCiSoD dan LKiS, 2016.

Musa, Ali Maykur, Pemikiran dan Sikap Politik Gus Dur, Jakarta: Erlangga, 2010.

${ }^{39}$ Gusdurian.net, " 9 Nilai Pemikiran Gus Dur", http://www.gusdurfiles.com Sembilan nilai utama Gus Dur. 
Suwardiyamsyah, Pemikiran Abdurrahman Wahid tentang Toleransi Beragama, AL-IRSYAD, Vol. 8, No. 1, Januari - Juni 2017.

Abidin, Zainal, Filsafat Manusia, Memahami Manusia Melalui Filsafat, Bandung: Rosda Karya, 2000.

Salim, Peter dan Salim, Yenny, Kamus Besar Bahasa Indonesia Kontemporer, Jakarta: Modern English Press, 1991.

Masruri, Siswanto Humanitarianisme Soedjatmoko: Visi Kemanusiaan Yogyakarta: Pilar Media, 2005.

Nelson, Zulkifli dan Dardiri, Inklusivisme dan Humanisme Pesantren, TOLERANSI: Media Komunikasi umat Beragama Vol. 8, No. 2, Juli-Desember 2016.

Barton, Greg gagasan Islam Liberal di Indonesia: pemikiran Neo-Modernisme Nurcholish Madjid, Djohan Effendi,Ahmad Wahid dan Abdurrahman Wahid, Jakarta: Paramadina Pustaka Antara, 1999.

Hidayat, Komarudin dan Gaus, Ahmad Passing Over: Melintasi Batas Agama, Jakarta: Gramedia Pustaka Utama, 1998.

Magnis Suseno, Franz, factor-factor yang mendasari terjadinya konflik Antar Etnis dan agama di Indonesia: pencegahan dan pemecahan, dalam konflik komunal di Indonesia saat ini Jakarta: INIS, 2003.

Gusdurian.net, " 9 Nilai Pemikiran Gus Dur", http://www.gusdurfiles.com Sembilan nilai utama Gus Dur.

Santalia, Indo, K.H. Abdurrahman Wahid, Agama dan Negara, Pluralisme, Demokratisasi, dan Pribumisasi, Al-Adyan, Vol. 1, No. 2, Desember 2015.

Nugroho, Aryanto, Jejak Langkah Guru Bangsa Footprints Of The Guru, Keep Gus Dur's Spirit. Semarang: EIN INSTITUTE. 2010.

Suaedy, Ahmad dan Abshar Abdalla, Ulil, Gila Gus Dur: Wacana Pembaca Abdurrahman Wahid, Yogyakarta: PT LkiS Printing Cemerlang, 2010. 